502. 4 (477.8), $504.062(477.8)$

ьвівський н ціон льний університет імені в н вул. . орошенк , 41, м. ввів, 79000, кр їн

ро н лізов но розміщення мережі природних з повідників, н ціон льних природних т регіон льних л ндш фтних п рків хідного олино- оділля. изн чено, н скільки мереж цих з повідних об'єктів репрезентує природно-територі льні комплекси р йону дослідження. пропонов но оптимізув ти іiі в н прямі підвищення рівня репрезент тивності шляхом створення регіон льних л ндш фтних п рків.

лючові слов : природно-з повідний фонд, природний з повідник, н ціон льний природний п рк, регіон льний л ндш фтний п рк, природно-територі льні комплекси.

кр їні пит ння розширення природно-з повідного фонду н був є держ вної в ги. ро це свідч ть ук зи резидент кр їни про створення нових н ціон льних природних п рків протягом 2009-2010 pр. г лом з роки нез лежності площ природно3 повідного фонду кр їни збільшил сь м йже втричі і ст ном н 01.01.2010 р. ст новил 5,4\% від з г льної площі кр їни. ідповідно до з кону кр їни “ ро з г льнодерж вну прогр му формув ння н ціон льної екологічної мережі кр їни н 20002015 роки" ч стк природно-з повідного фонду від площі держ ви повинн ст новити 10,4 \%, з них н ціон льні природні п рки - 3,9\%, природні т біосферні з повідники 1,2, інші к тегорії природно-з повідного фонду - 5,3\% [1]. ому суч сн мереж 3 повідних об'єктів не репрезентує повною мірою л ндш фтну і біотичну різном нітність природних л ндш фтів.

продовж кількох десятиріч ф хівці н д ють перев гу фізико-геогр фічній концепції розбудови мережі природно-з повідного фонду ( ), згідно з якою ціон льн екологічн мереж повинн відобр ж ти геогр фічні особливості поширення природно-територі льних комплексів ( ) різного рівня розмірності т різном нітність природних біоценозів. ому з с дничими проблем ми орг ніз ції репрезент тивної мережі об'єктів є виявлення л ндш фтного т біотичного різном ніття і відобр ження його в системі природоохоронних територій.

3 г льнення про л ндш фтну репрезент тивність мережі досліджув ного регіону в н уковій літер турі дост тньо не висвітлені. ерші спроби т кого уз г льнення є в пр цях . етрової, . рик $[12 ; 9$, с. 81$]$.

хідний регіон кр їни м є зн чне л ндш фтне і біотичне різном ніття. е є визн ч льним чинником у формув нні й територі льному розміщенні об'єктів ше дослідження стосується з хідної ч стини олино- оділля. ід хідним олино- оділлям ми розуміємо територію, як охоплює т кі фізико-геогр фічні обл сті: олинське олісся, олинську височинну обл сть, ле олісся, озтоцько- пільську горбо-

() удоб ., 2011 
гірну обл сть, хідноподільську височинну обл сть, ередньоподільську височинну обл сть [10, с. 224].

досліджув ній території розміщені чотири природні з повідники, десять н ціон льних природних п рків ( ) т вісім регіон льних л ндш фтних п рків. йбільшу ч стку з йм ють н ціон льні природні п рки - 73,3 \% від 3 г льної площі 3 повідних об'єктів, регіон льні л ндш фтні п рки з йм ють 16,4 \%, природні з повідники $10,3 \%$. зн чимо, що з ост нні кільк років н хідному олино- оділлі створено п’ять нових : ерм нсько- строзький, ременецькі гори, ністерський к ньйон, ум нськ ущ, івнічне оділля (рис. 1).

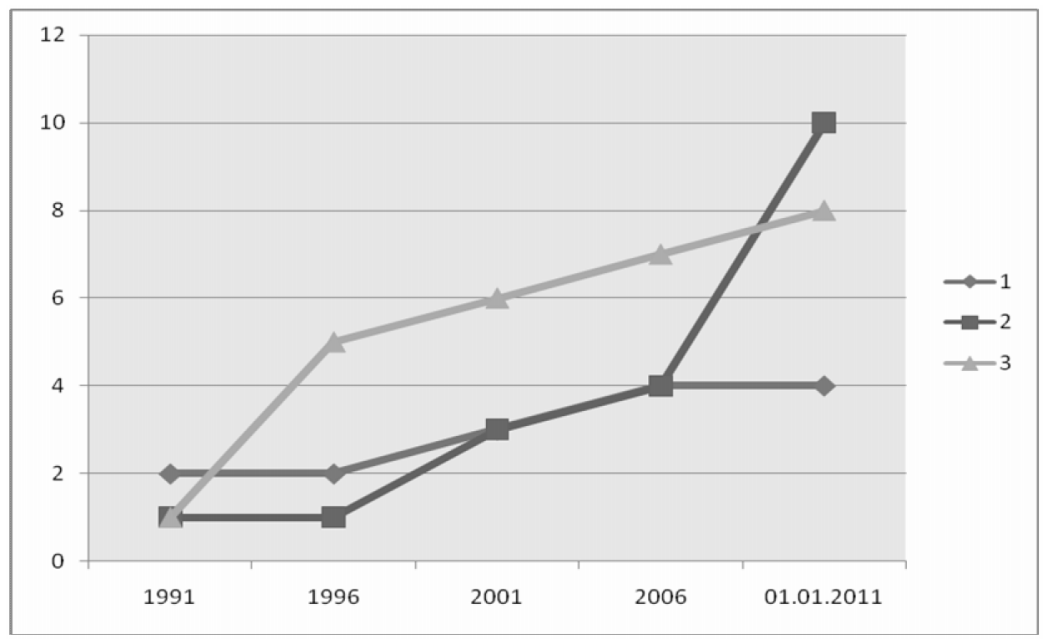

ис. 1. ин мік розвитку

(1),

(2) $\mathrm{T}$

(3) 3 період 1991-2011 pp.

сновне з вд ння цих об'єктів - репрезентув ти л ндш фтну і біотичну різном нітність регіону. озміщення з повідних об'єктів н території хідного олино- оділля є нерівномірним. риродно-територі льні комплекси регіону охоплені з повідним режимом у меж х природних з повідників ( ) - 0,7\% площі регіону, н ціон льних природних п рків $-5,3 \%$ т регіон льних л ндш фтних п рків ( ) - 1,2\%. обто мереж цих з повідних об'єктів охороняє 7,2 \% хідного олино- оділля, цей пок зник є оптим льним [1]. озглянемо, як мереж цих з повідних об'єктів репрезентує природні обл сті р йону дослідження.

риродні л ндш фти обл сті олинського олісся предст влені трьом н ціон льними природними п рк ми, двом природними з повідник ми т одним регіон льним л ндш фтним п рком, що ст новить 7 \% від 3 г льної площі обл сті (див. т блицю), ціон льні природні п рки цький (48 977 г ), ум нськ ущ (33 475,3 г) т рип'ять- тохід (39 315,5 г ) ст новлять 4,4 \% площі природних комплексів олинського олісся (рис. 2). ціон льний природний п рк рип'ять- тохід створено 2007 р. вн слідок реорг ніз ції однойменного н території олинської обл.

риродні з повідники івненський $(47$ 046,8 г ) і еремський $(2975,7$ г $)$ з йм ють $1,8 \%$ площі природних комплексів олинського олісся. егіон льний л ндш фтний п рк рип’ять- тохід (21 600 г ) охоплює 0,8 \% площі фізико-геогр фічної обл сті олинське олісся. 

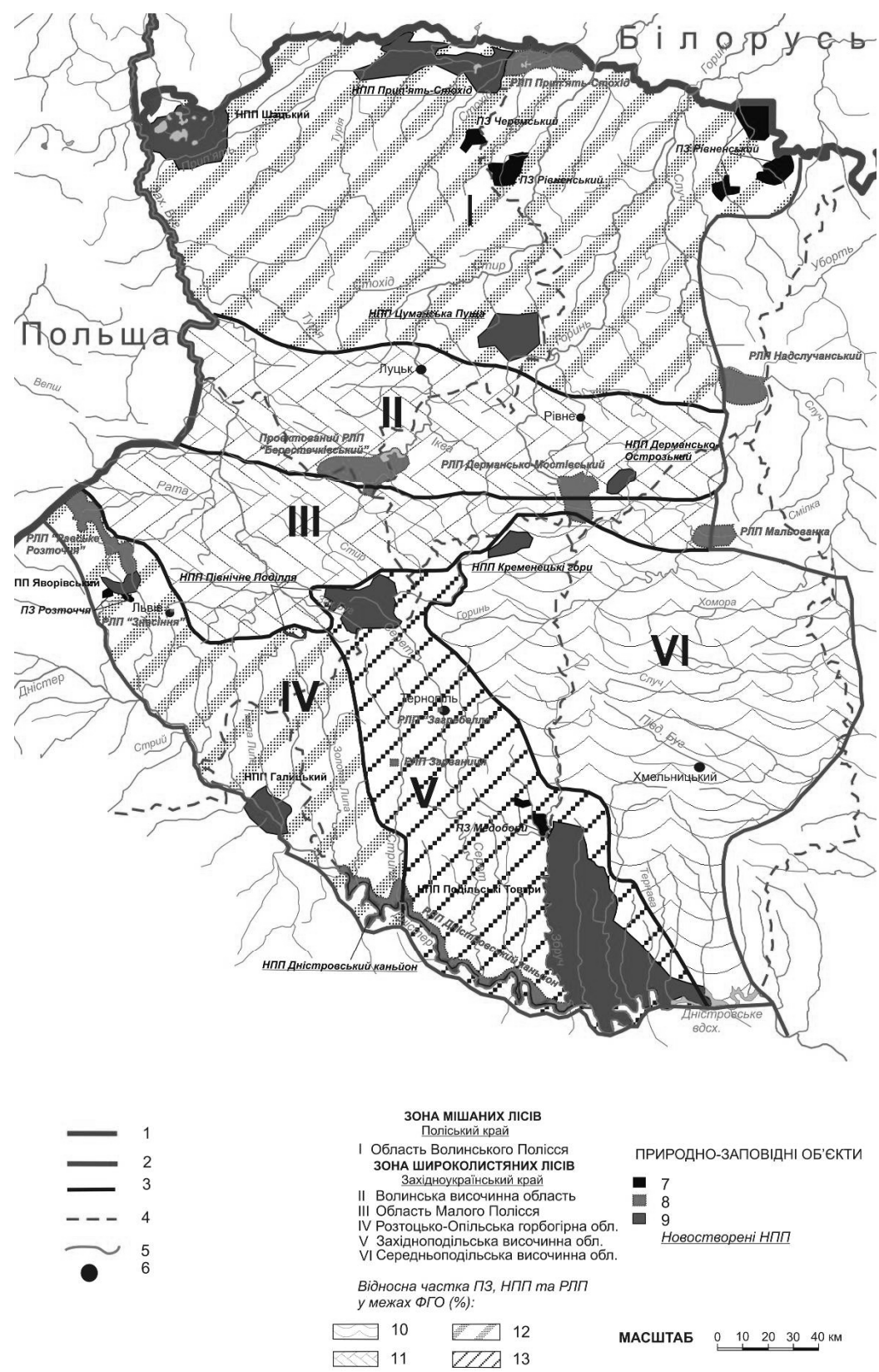

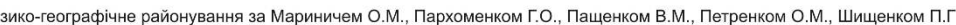
"Національний атлас України" 2008 р.

ис. 2. йбільші з повідні об'єкти хідного олино- оділля: 1 - держ вний кордон; 2 - меж олино- оділля; 3 - межі фізико-геогр фічних обл стей; 4 - межі дміністр тивних обл стей; 5 - річки; 6 - обл сні центри; 7 - природні з повідники; 8 - регіон льні л ндш фтні п рки; 9 - н ціон льні природні п рки; $10-<1 \% ; 11-1-5 \% ; 1-5-10 \% ; 13->10 \%$. 
ериторі льн структур мережі , т у меж х фізико-геогр фічних обл стей досліджув ного регіону

\begin{tabular}{|c|c|c|c|c|c|c|c|c|c|}
\hline \multirow{2}{*}{\multicolumn{2}{|c|}{$\begin{array}{l}\text { ізико-геогр фічні } \\
\text { зони т обл сті }\end{array}$}} & \multicolumn{8}{|c|}{$\begin{array}{c}\text { ереж природних з повідників, н ціон льних природних п рків т } \\
\text { регіон льних л ндш фтних п рків }\end{array}$} \\
\hline & & \multirow[b]{2}{*}{ 站芯 } & \multirow[b]{2}{*}{ 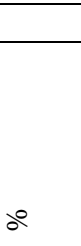 } & \multirow[b]{2}{*}{ 章它 } & \multirow[b]{2}{*}{ 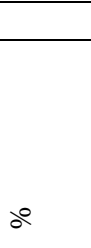 } & \multirow[b]{2}{*}{ 当 } & \multirow[b]{2}{*}{ 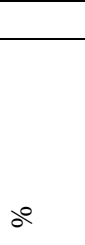 } & \multicolumn{2}{|c|}{$30 \mathrm{M}$} \\
\hline 3в & 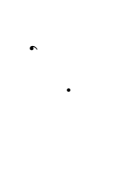 & & & & & & & 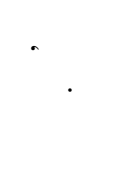 & 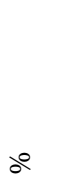 \\
\hline \multicolumn{10}{|c|}{$\begin{array}{c}\text { он міш них (хвойно-широколистяних) лісів } \\
\text { оліський } к р \ddot{u}\end{array}$} \\
\hline $\begin{array}{c}\text { олинське } \\
\text { олісся }\end{array}$ & 2775,3 & 50,023 & 1,8 & 121,767 & 4,4 & 21,600 & 0,8 & 193,39 & 7 \\
\hline \multicolumn{10}{|c|}{$\begin{array}{l}\text { он широколистяних лісів } \\
\text { хідноукр їнський кр й }\end{array}$} \\
\hline $\begin{array}{r}\text { олинськ } \\
\text { височинн }\end{array}$ & 925,1 & - & - & 5,448 & 0,6 & 10,000 & 1,2 & 15,448 & 1,8 \\
\hline $\begin{array}{c}\text { ле } \\
\text { олісся }\end{array}$ & 832,6 & - & - & - & - & 13,87 & 1,7 & 13,87 & 1,7 \\
\hline $\begin{array}{l}\text { озтоцько- } \\
\text { пільськ }\end{array}$ & 782,2 & 2,084 & 0,3 & 20,232 & 2,6 & 25,275 & 3,2 & 47,591 & 6.1 \\
\hline $\begin{array}{r}\text { хідно- } \\
\text { подільськ } \\
\end{array}$ & 1278,4 & 9,516 & 0,7 & 279,919 & 21,9 & 26,307 & 2,1 & 315,742 & 24,7 \\
\hline $\begin{array}{r}\text { ередньо- } \\
\text { подільськ }\end{array}$ & 1682 & - & - & 11,296 & 0,7 & 2.037 & 0.1 & 13,333 & 0,8 \\
\hline $\begin{array}{l}\text { зом по } \\
\text { perioнy }\end{array}$ & 8275,6 & 61,623 & 0,7 & 438,662 & 5,3 & 99,089 & 1,2 & 599,374 & 7,2 \\
\hline
\end{tabular}

ндш фти олинської височинної обл сті охоплені охороною ерм нськострозький (5 448,3 г ) т ч стиною ерм нсько- остівський (10 000 г ), що ст новить $1,8 \%$ від площі обл сті.

ерм нсько- остівський (7 800 г ) т льов нк (6 070 г ) ст новлять 1,7 \% природно-територі льних комплексів лого олісся. риродні комплекси лого олісся недост тньо репрезентов ні мережею цих об'єктів. окрем , у структурі мережі нем природних з повідників т н ціон льних природних п рків.

ля озтоцько- пільської горбогірної фізико-геогр фічної обл сті х р ктерн розвинут мереж з повідних об'єктів. природному з повіднику озточчя (2 084,5 г ), ворівському (7 078,6 г ), ністерський к ньйон (2 829,2 г ), івнічне оділля (640 г ) т лицькому (9 684,8г ) н ціон льних природних п рк х охоплено охороною 2,6 \% площі природних комплексів озточчя й пілля. егіон льні л ндш фтні п рки ( вське озточчя, несіння, ністерський к ньйон) з безпечують охороною 3,2 \% л ндш фтів обл сті.

території хідноподільської височинної фізико-геогр фічної обл сті є природний з повідник едобори (0,7 \% площі обл сті), н ціон льні природні п рки одільські овтри, ністерський к ньйон т івнічне оділля (21,9\%). егіон льні л ндш фтні 
п рки ністерський к ньйон, гребелля, рв ниця репрезентують 2,1\% природних комплексів обл сті (див. рис. 2). г льний пок зник охорони мережі цих об'єктів для обл сті ст новить 24,7\%, з вдяки одільські овтри (256971 г).

ередньоподільські природні комплекси вкр й недост тньо репрезентов ні мережею об'єктів . они є під охороною в меж х н ціон льного природного п рку ременецькі гори (11 296 г ) т ерм нсько- остівський (2 037 г ), що ст новить 0,8 \% від площі обл сті. ей пок зник н йнижчий у всьому регіоні. структурі мережі нем природних з повідників. ільшість об'єктів місцевого зн чення.

скільки основним з вд нням у р зі формув ння н уково-обгрунтов ної мережі з повідних об’єктів є з безпечення її репрезент тивності, то н явні диспропорції в охопленні з повідним режимом природно-територі льних комплексів різного рівня розмірності необхідно вв ж ти суттєвим недоліком територі льної структури н явної мережі $[9$, с. 86].

ля оптиміз ції мережі з повідних об’єктів рекомендують підвищув ти рівень іiї репрезент тивності шляхом створення регіон льних л ндш фтних п рків. ериторія

хідного олино- оділля густоз селен , з високим ступенем розор ності, це унеможливлює створення дост тньої кількості , т відміну від н ціон льних природних п рків, можн створюв ти поблизу великих міст. егіон льні л ндш фтні п рки м ють перев ги с ме як орг ніз ційн форм охорони природи: д ють змогу вр ховув ти роздрібленість території, тр нсформов ність природних умов, високі нтропогенні н в нт ження, т кож створюють передумови збереження невеликих, ле досить добре збережених і цінних природних комплексів [3, с. 12].

гідно 3 коном кр їни “ ро природно-з повідний фонд кр їни”, регіон льні л ндш фтні п рки є природоохоронними рекре ційними уст нов ми місцевого чи регіон льного зн чення, які створюють з метою збереження в природному ст ні типових бо унік льних природних комплексів т об'єктів і з безпечення умов для орг нізов ного відпочинку н селення. х створюють, з звич й без вилучення земельних ділянок у їхніх вл сників бо користув чів [2, с. 217]. е зн чно полегшує процедуру створення.

егіон льні л ндш фтні п рки виконують т кі з вд ння: збереження цінних природних т історико-культурних комплексів т об'єктів; створення умов для ефективного туризму, відпочинку т інших видів рекре ційної діяльності в природних умов х з дотрим нням режиму охорони з повідних природних комплексів і об'єктів; сприяння екологічній освітньо-виховній роботі [2, с. 217].

собливістю регіон льних л ндш фтних п рків є те, що створення їх м є н меті як охорону і р ціон льне використ ння цінних природних територій, т к і збереження історико-культурних комплексів т об'єктів, здійснення рекре ційної діяльності. ме в цій к тегорії зближуються дві лінії охорони, які існують в кр їні, - охорони об'єктів природи т історико-культурних об'єктів.

об збільшити площу охорони природних комплексів олинської височинної обл сті, пропонуємо створити регіон льний л ндш фтний п рк ерестечківський ( емидівський) площею близько 30000 г [6; 11]. території лого олісся потрібно створити мінімум ще один у 6 сейні річки хідний уг із ч сом реорг нізув ти в н ціон льний природний п рк. ля збільшення репрезент тивності ередньоподільської височинної фізико-геогр фічної обл сті доцільно створити регіон льні л ндш фтний п рк дзбруч нський у р йоні витоку р. бруч. ьогодні н території хідного олино- оділля розробляють проекти орг ніз ції нових $\quad$ : ешуцько- лекс ндріїв- 
ський, емидівський, огориння, ересопницький кр й, тілецький, няжий ліс, к л подільське збруччя [12, с. 55].

тже, територія мережі природних з повідників, н ціон льних природних т регіон льних л ндш фтних п рків охоплює 7,2 \% площі хідного олино- оділля. риродні л ндш фти регіону охоплені з повідним режимом нерівномірно. йліпше репрезентов ні мережею з повідних об'єктів т кі фізико-геогр фічні обл сті: хідноподільськ височинн обл сть-24,7\% (від площі обл сті), олинське олісся - 7, озтоцькопільськ височинн обл сть $-6,1 \%$; ці пок зники є оптим льними. едост тньо репрезентов ні мережею , т ередньоподільськ височинн обл сть $-0,8 \%$, олинськ височинн обл сть $-1,8$, ле олісся $-1,7 \%$. ля того, щоб поліпшити репрезент тивність цих фізико-геогр фічних обл стей, н н шу думку, потрібно орг нізовув ти нові регіон льні л ндш фтні п рки, які м ють простішу процедуру створення, ніж н ціон льні природні п рки. дн к сьогодні є великі проблеми з менеджментом регіон льних л ндш фтних п рків, що потребують н г льного вирішення.

розвинених кр їн х світу кількість зн чно перевищує кількість н ціон льних природних п рків, і міжн родний досвід свідчить, що ця к тегорія $\quad$ м є перспективи для розвитку з умови підняття їхнього ст тусу.

1. кон кр їни “ ро г льнодерж вну прогр му формув ння н ціон льної екологічної мережі кр їни н 2000-2015 роки”. 21 верес. 2000 р. № 1989-III [ лектронний ресурс]. ежим доступу : http://www.rada.gov.ua

2. кон кр їни “ ро природно-з повідний фонд кр їни” від 16 червня 1992 р. // кологічне 3 конод вство кр їни. .: рінком. 2001. . 206-235.

3. ндрієнко . . уково-методичне т норм тивно-пр вове з безпечення створення т діяльності регіон льних л ндш фтних п рків кр їни / . . ндрієнко, . . р ф ентр, 2004. 53 с.

4. ндрієнко . . истем к тегорій природно-з повідного фонду кр їни т пит ння їі оптиміз ції / . . ндрієнко, . . нищенко, . . лєстов [т ін.]. . : ітосоціоцентр, 2001. 60 с.

5. повідн спр в в кр їні : н вч. посібник / ред. . . родзинського і . . теценк . . еогр фік , 2003. $306 \mathrm{c}$.

6. укурудз . . егіон льні л ндш фтні п рки як ефективний з сіб збереження біотичного різном ніття т культурно-історичної сп дщини / . . укурудз // ук. 3 п. ерноп. пед. ун-ту. ім. . н тюк . ер. геогр. 2004. № 2 ( . 2). . 241-246.

7. ринич . . ізичн геогр фія кр їни: н вч. посібник / . . ринич, . . ищенко. 3-те вид., стереотип. . : н ння, 2006. 511 с.

8. ціон льн доповідь про ст н н вколишнього природного середовищ в кр їні у 2009 р. [ лектронний ресурc]. ежим доступу : http://www.menr.gov.ua

9. етров . . труктур мережі з повідних об'єктів з ходу кр їни / . . етров // повідн спр в в личині, н оділлі т олині. 2004. ип. 14.8. . $80-88$.

10. уденко . . ціон льний тл с кр їни / . . уденко. . : ртогр фія, 2008. 440 с.

11. удоб . . роблеми орг ніз ції з повідних об'єктів в меж х тр нсрегіон льних територій / . . удоб // існик ін-ту пед. освіти. ер. геогр. 2009. ип. 1. . 114-117.

12. рик . . еогр фічні з с ди формув ння і розвитку регіон льних природоохоронних систем (концепту льні підходи, пр ктичн ре ліз ція) / . . рик. ернопіль : ідручники і посібники, 2009. 320 с. 


\section{REPRESENTATION ANALYSIS OF LARGE RESERVES UNITS NETWORK IN WESTERN VOLYN-PODILLIA REGION}

\section{Khudoba}

Ivan Franko National University of Lviv, . Doroshenko St., 41, UA - 79000 Lviv, Ukraine

The article is dedicated to the analysis of the network of reserves, national parks and regional landscape parks in Western Volyn-Podillia region. The research has determined their level of representation of nature-territorial complexes of the region itself. It has been suggested in the article to optimize these objects in order to increase their representation by means of creating more regional landscape parks.

Key words: nature reserves stock, natural reserve, national park, regional landscape park, natureterritorial complexes.

$$
\text { - удоб }
$$

$$
\begin{aligned}
& \text { ьвовский н цион льный университет имени в н } р \text { нко, } \\
& \text { ул. . орошенко, 41, г. ьвов, 79000, кр ин }
\end{aligned}
$$

риведено н лиз сети природных з поведников, н цион льных природных и регион льных л ндш фтных п рков п дной олыно- одолии. пределено репрезент тивность сети этих 3 поведных объектов физико-геогр фическому р йониров нию кр ины. редложено оптимизиров ть сеть объектов путем созд ния новых регион льных л ндш фтных п рков.

лючевые слов : природно-з поведный фонд, природный з поведник, н цион льный природный п рк, регион льный л ндш фтный п рк, природно-территори льные комплексы.

т ття н дійшл до редколегії 07.07.2010 рийнят до друку 16.11.2010 